\title{
The Five Aggregates Learning Model via Buddhist Catechism Method on Mobile Learning for Development of Thinking Buddhist Critical
}

\author{
Sorraya Priaoprasit, Prachyanun Nilsook, and Pullop Piriyasurawong
}

\begin{abstract}
The objectives of this research were: 1) to design and form the Five Aggregates learning model via Buddhist Catechism method on mobile learning for development of critical thinking Buddhist model, 2) to evaluate the Five Aggregates learning model via Buddhist Catechism method on mobile learning for development of critical thinking Buddhist model. The findings revealed that the designed model defined as the Five Aggregates learning model had included five (5) steps.

The evaluation of this study was conducted by seven (7) selected specialists. The first evaluation result was elements of designing Five Aggregates learning model which included 1) principles and concepts, 2) objectives of Five Aggregate learning model, 3) element of Five Aggregate learning model, 4) Five Aggregates teaching method, 5) Catechism teaching method, 6) teaching and learning element of m-learning, and 7) critical thinking Buddhist model. It was followed by the second evaluation result of steps of designing Five Aggregates learning model that comprised of 1) setting goals and objectives, 2) preparation, 3) accessing to mobile learning system, 4) learning and teaching activities, and 5) evaluation. The overview result of the former showed a high rating scale of suitability $(\bar{x}=4.77$, S.D. $=0.20$ ) while the latter presented the highest rating scale of suitability $(\bar{x}=4.54$, S.D. $=0.47)$.
\end{abstract}

Index Terms - The five aggregates learning model, mobile learning, Buddhist Catechism method, development of critical thinking Buddhist model.

\section{INTRODUCTION}

Education plays a vital role in developing human resources and nation. According to the National Scheme of Education B.E. 2545-2559 (2002-2016), education requires development focusing on both knowledge and virtue. Based on Section 6, the educational management aims to encourage Thai people to achieve physical and mental wellbeing as well as applying knowledge, virtue, moral, culture in life for a peaceful living in the society. The National Scheme of Education has been revised to agree with the recent National Education Act, and the $10^{\text {th }}$ National Economic and Social Development Plan. Additionally, it also adjusted to be in line with the second educational reform in Thailand that emphasizes the Philosophy of Sufficiency Economy, morality, ethics, intelligence, happiness, national pride, consolidation of democracy, and anti-corruption. Thailand will be a society of morality and place for lifelong learning [1]. A former

Manuscript received February 16, 2015; revised May 8, 2015.

The authors are with the Faculty of Technical Education, King Mongkut's University of Technology North Bangkok (KMUTNB), Thailand (e-mail: chantana.p@rmutp.ac.th). minister of the Office of the Prime Minister, Mr. Mechai Viravaidya said the education in Thailand is lack of preparedness for the future living skills of student. Students are only taught the followership skills, but the leadership skills. Students learn things, but they are lack of understanding and encouragement. It is time to change because the young generation today is our nation's future Educational development depends on how much students play roles in society.

Modern science and technology and the advanced internet connection system have been assisting learning activities, for instance, web-based learning, online study, learning on computer and internet (CAI on Web) [2] including mobile learning system through cell phone, and laptop using the wireless technology called M-learning [3]. In the digital world where mobile phone is accessible easily by everyone, learning through mobile application is a challenging face of Thailand educational system. Mobile device has offered various forms of learning management and the learners are able to manage knowledge anywhere and anytime [4]. The mobile learning concept is a reflection of the $21^{\text {st }}$ Century Learning Framework. The Partnership For 21st Century Skills defines the required basic knowledge for learners which include information, media, information and communications technology (ICT). [5]. Ten strategic technology trends in 2014 are compiled by Gartner. The first three technologies are related to mobile application which has previously been identified in the compilation of Gartner for three to four years. Mobile Device Diversity and Management: Gartner has paid attention to mobile device for two to three years and pointed out that PC has been replaced by mobile device such as smart phone, and tablet. The companies has adopted this mobile technology to be used in the workplace (BYOD) causing the increasing number of mobile device at about two to three times than the number of their employees. However, security within the organization is a priority concern so that policy of ICT architecture is set to ensure the safety.

The Five Aggregates teaching model is considered the new innovation in Thailand of which teaching ethics and Thai social etiquette will create optimistic and critical thought (think correctly, think the right way, think reasonably, and think meritoriously [6]. The Five Aggregates learning model includes five (5) steps: planning of stimulus (form or "rupa" in Pali), feeling (sensation or vedana in Pali), analyzing reason and synthesizing perception (cognition or sanna in Pali), value judgment (mental formation or sankhara in Pali), and characterization (consciousness or vinnana in Pali) [7]. Student center is essential in the education and meanwhile, morality, self-discipline, and sense of responsibility are 
applied in the lessons. The Buddhist Catechism teaching is one of the other nine (9) teaching approaches in Buddhism. The learners are encouraged by an instructor to practice questions and answers either by doing among themselves or with the instructor. The instructor will only ask questions, but the learners can be asking or replying. With this teaching tactic, the learners will experience self-learning and are able to think and find solution independently [8].

The examiner has recognized the value of the Five Aggregates teaching model and believed in the10 virtues of vocational student attribute which are responsibility, diligence, economizing, honesty, public consciousness, harmony, discipline, hygiene, courtesy, avoiding allurements. [9]. The Buddhist Catechism teaching method creates a sense of morality and virtue as well as enhancing Buddhism-based critical thinking, (think the right way, think correctly, think reasonably, and think meritoriously).

\section{RESOURCE OBJECT}

The objectives of the research were to 1) design and form the Five Aggregates learning model via Buddhist Catechism method on mobile learning for development of critical thinking Buddhist mode an 2) to evaluate the Five Aggregates learning model via Buddhist Catechism method on mobile learning for development of critical thinking Buddhist model.

\section{RESOURCE METHODOLOGY}

The research methodology included 2 major steps: designing and forming the model, and evaluating by specialists.

Step 1 - The examiner designed and developed the Five Aggregates Critical Thinking Buddhist model using the instruction design of ADDIE MODEL. ADDIE (Analysis, Design, Development, Implement, and Evaluate) is part of the ISD family (Instructional System Design). It includes such other models as the Dick \& Carey (2004) and Kemp (Gustafson, Branch, 1997) models [10], [11].

Step 2 - The seven (7) selected specialists evaluated the Five Aggregates Critical Thinking Buddhist model.

Population and Sample Population refers to those specialists in instruction design related to information technology and Buddhism studies. Sample refers to the seven (7) selected specialists (Purposive Sampling) in instruction design related to information technology and critical thinking Buddhist model.

\section{RESOURCE FINDING}

Step 1 Result of designing, forming, and evaluating the Five Aggregates Critical Thinking Buddhist model were concluded accordingly to the designing and developing process using the ADDIE MODEL as follows:

1) Analysis - This step involved analyzing in order to identify details and element needed for forming the Five Aggregates learning model via Buddhist Catechism method on mobile learning for development of critical thinking Buddhist model.
2) Design - This step was designing the Five Aggregates learning model via Buddhist Catechism method on mobile learning for development of critical thinking Buddhist model.

3) Development - This step was developing the Five Aggregates learning model via Buddhist Catechism method on mobile learning for development of critical thinking Buddhist model.

4) Implementation - In this step, the created learning model was evaluated by the specialists to determine its suitability as per individual aspect.

5) Evaluation - the output of the Five Aggregates learning model via Buddhist Catechism method on mobile learning for development of critical thinking Buddhist model was evaluated by the seven (7) selected specialists.

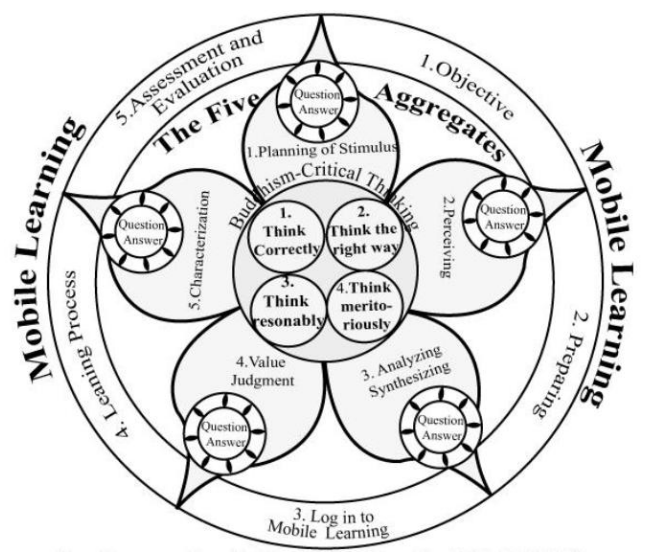

Fig. 1. Five aggregates critical thinking Buddhist model.

Element of the Fig. 1: Five Aggregates Critical Thinking Buddhist MODEL

1) Critical thinking Buddhist model comprised of think correctly, think the right way, think reasonably, and meritoriously.

2) Five Aggregates Teaching Method, stated by Department of Curriculum and Instruction Development, Ministry of Education [1] refers to the instruction within the setting of Buddhism principle called the five skandhas (Sanskrit) or khandhas (Pal i). The Five Aggregates include form (rupa), sensation (vedana), perception (sanna), mental formation (sankhara), and consciousness (vinnana).

- Planning of Stimulus (form or rupa) -Various situations were specified by an instructor to stimulate sensation of learners.

- Sensation (sensing or vedana) - Learners physically and mentally experienced stimulus through contact of the six (6) faculties (eye, ear, nose, tongue, body, mind). The instructor assured that the learners literally felt things through the right sense of organ. Questioning was necessarily used to introduce or uncover the faculties.

- Analyzing reason and synthesizing perception (cognition or sanna) - Learners were questioned of what, where, when, and how in order to identify how they registered or recognized things and what kind of feeling their mind carried.

- Value judgment ( mental formation or sankhara) Learners were assigned to criticize if it is wrongfulness, righteousness, virtue, evil, appropriateness including 
those should or should not.

- Characterization ( consciousness or vinnana) - The implied questions were persuasively used to convince learners on virtues and moral. It was expected to acquire a self-center based answer from the learners.

3) Buddhist Catechism teaching method relies on the question and answer between learners and program application. Questions were integrated in the Five Aggregates.

4) Mobile Application and 5. MLMS (m-Learning Management System)

- Content management system enables learning management to be managed on (MLMS) Mobile Learning Management System.

- Teaching and learning activity management system is available on the Mobile Learning Management System (MLMS). The system enables learners to be exposed to the designed activities under the determined objectives of the subject for enhancing knowledge, attitude, and skill.

- Equipment refers to those electronic devices operated in the learning system, wireless internet connection, (MLMS) Mobile Learning Management System (Mobile Moodle), and mobile device.

- Channels used to communicate between instructor and learner or learner and learner, including those individuals who involved can be described as the following medium: Line, Face Time, Hangout, Web board, Chat room etc.

- Instructor/teacher, learner, system administrators

- Experimenting, measurement, and evaluation

Step 2 Evaluation Result of Five Aggregates learning model via Buddhist Catechism method on mobile learning for development of critical thinking Buddhist model.

TABLE I: ElEMENTS OF DESIGNING to FIVE AgGREGATES CRITICAL THINKING BUDDHIST MODEL

\begin{tabular}{|c|c|c|}
\hline \multirow{2}{*}{ Details of Evaluation List } & $\underline{\text { Result }}$ & \multirow[t]{2}{*}{ Rating } \\
\hline & $\overline{\bar{x}}$ & \\
\hline 1. Principles and Concepts & 4.71 & 0.75 highest \\
\hline 2. Objectives of Five Aggregate learning model & 4.85 & 0.37 highest \\
\hline $\begin{array}{l}\text { 3. Element of Five Aggregate Learning Model } \\
\text { 3.1 Five Aggregates Teaching Method } \\
\text { 3.2 Buddhist Catechism teaching method } \\
\text { 3.3 Critical thinking Buddhist } \\
\text { 3.4 Mobile Application and } \\
\text { 3.5. MLMS (m-Learning Management System) }\end{array}$ & 4.71 & 0.75 highest \\
\hline $\begin{array}{l}\text { 4. Five Aggregates Teaching Method } \\
4.1 \text { sensation (vedana), } \\
4.2 \text { perception (sanna), } \\
4.3 \text { mental formation (sankhara), } \\
4.4 \text { consciousness (vinnana). } \\
\end{array}$ & 4.71 & 0.75 highest \\
\hline 5. Catechism Teaching method (Question \& Answer) & 4.85 & 0.37 highest \\
\hline 6. Teaching and Learning Element of m-Learning & 4.85 & 0.37 highest \\
\hline $\begin{array}{l}7 . \text { Critical Thinking Buddhist Model } \\
7.1 \text { think correctly, } \\
7.2 \text { think the right way. } \\
7.3 \text { think reasonably, } \\
7.4 \text { meritoriously. }\end{array}$ & 4.71 & 0.75 highest \\
\hline Overview & 4.77 & 0.20 highest \\
\hline
\end{tabular}

The result in Table I shows that the rating scale of the details of evaluation list of elements of designing to Five
Aggregates Critical Thinking Buddhist model that the topic of objectives of Five Aggregate learning model, catechism teaching method (question \& answer) and teaching and learning element of m-learning were highest. $(\bar{x}=4.85)$. The average mean score of overview was highest too $(\bar{x}=4.77)$.

TABLE II: StePs OF DESIGNING: STEPS OF DESIGNING FIVE AGGREGATES LEARNING MODEL VIA BUdDHIST CATECHISM METHOD ON MOBILE LEARNING FOR DEVELOPMENT OF CRITICAL THINKING BUDDHIST MODEL

\begin{tabular}{|c|c|c|c|}
\hline \multirow{2}{*}{ Details of Evaluation List } & \multicolumn{2}{|c|}{ Result } & \multirow[t]{2}{*}{ Rating } \\
\hline & $\bar{x}$ & S.D. & \\
\hline \multicolumn{4}{|l|}{ Mobile learning } \\
\hline 1. Setting Goals and Objectives & 4.50 & 0.30 & highest \\
\hline \multicolumn{4}{|l|}{ 2. Preparation } \\
\hline 2.1 Equipment & 4.42 & 0.14 & high \\
\hline 2.2 Manpower & 4.52 & 0.08 & highest \\
\hline 3. Accessing to mobile learning system & 4.50 & 0.10 & highest \\
\hline \multicolumn{4}{|l|}{ 4. Learning and Teaching Activities } \\
\hline 4.1 Questioning for Stimulus & 4.66 & 0.08 & highest \\
\hline 4.2 Questioning for Sensing & 4.57 & 0.00 & highest \\
\hline 4.3 Questioning for Analyzing reason, knowledge, & 4.57 & 0.00 & highest \\
\hline and Virtues & 4.57 & 0.00 & highest \\
\hline $\begin{array}{l}\text { 4.4 Questioning for synthesizing, concluding, and } \\
\text { value judging }\end{array}$ & 4.57 & 0.00 & highest \\
\hline \multicolumn{4}{|l|}{$\begin{array}{l}\text { 4.5 Questioning for evaluating Knowledge and } \\
\text { Virtue Appreciation }\end{array}$} \\
\hline 5. Evaluation & 4.57 & 0.00 & highest \\
\hline Overview & 4.54 & 0.47 & highest \\
\hline
\end{tabular}

The result in Table II shows that the rating scale of the Steps of designing Five Aggregates learning model via Buddhist Catechism method on mobile learning for development of critical thinking Buddhist model that the topic of Questioning for Stimulus was highest. $(\bar{x}=4.66)$. The average mean score of overview was highest too $(\bar{x}=4.54)$.

\section{RESOURCE FINDINGS CONCLUSION}

This research aimed to design, develop, and evaluate the Five Aggregates Critical Thinking Buddhist model. The Five Aggregates Learning approach consists of five (5) steps: 1) planning of stimulus (rupa), feeling or sensing (vedana), analyzing reason and synthesizing perception (sanna), value judgment (sankhara), and characterization (vinnana). The method focused on questioning and answering between the learners and the application in order to find connection between or Yes or No and Why. Each aspect of the Five Aggregates was added with questions. The mobile application was designed based on the 14 steps of courseware. The m-Learning Management System - MLMS consisted of 1) content management system, 2) teaching and learning activity system, 3) Mobile Learning Management System - MLMS (Mobile Moodle), mobile device, 4) communication medium between instructor and learner or learner and learner, including those involved such as Line, Face Time, Hangout, Web board, and Chat room 5) instructor, learner, system administrators, and 6) experimenting, measurement and evaluating. The critical thinking Buddhist model were described as think the right way, think correctly, think reasonably, and think meritoriously.

The evaluation of this study was conducted by seven (7) selected specialists. The first evaluation result was elements of designing Five Aggregates learning model which included 
1) principles and concepts, 2) objectives of Five Aggregate learning model, 3) element of Five Aggregate learning model, 4) Five Aggregates teaching method, 5) Catechism teaching method, 6) teaching and learning element of m-learning, and 7) critical thinking Buddhist model. It was followed by the second evaluation result of steps of designing Five Aggregates learning model that comprised of 1) setting goals and objectives, 2) preparation, 3) accessing to mobile learning system, 4) learning and teaching activities, and 5) evaluation. The overview result of the former showed a high rating scale of suitability $(\bar{x}=4.77$, S.D. $=0.20$ ) while the latter presented the highest rating scale of suitability $(\bar{x}=$ 4.54 , S.D. $=0.47$ )

\section{ACKNOWLEDGEMENTS}

The authors also thanks for the supports of Thonburi Commercial College and Vocational Education Technology Research Center and Innovation and Technology Research Center at Science and Technology Research Institute, King Mongkut's University of Technology North Bangkok which supported this research.

\section{REFERENCES}

[1] Ministry of Information and Communication Technology, ICT 2020 Conceptual Framework of Thailand, $1^{\text {st }}$ Edition, Bangkok: Ministry of Information and Communication Technology, King Mongkut's University of Technology North Bangkok Publishing, pp. 5-7, 2011.

[2] M. Teantong, Courseware Design and development for CAI, Bangkok: King Mongkut's University of Technology North Bangkok Publishing, 2002, p. 235

[3] M. Theanthong, "M-learning: A new paradigm of e-learning," Technology and Communication for Education Journal, vol. 1, pp. 3-11, 2004.

[4] P. Nilsook, "M-learning - Teaching and learning via mobile telephone," Journal of Technical Education Development, vol. 20, pp. 25-30, April-June 2008.

[5] J. Bellanca and R. Brandt, 21st Century Skills Rethinking How Students Learn, Bangkok: Openworlds Publisher, 2011, pp. 23-28.

[6] B. P. Cuna, Buddhist Way of Thinking according to NME, Tammaspa Publisher, Lue Thamma Institute, 2007, pp. 19-20.

[7] P. Kumut, "The five aggregates moral education teaching model," Government Journal, pp. 41-45, February 1985.

[8] Division of Educational Research, Ministry of Education, Report of research on Secondary Efficient Educational Innovation, Bangkok: Kurusapa Publisher, 1992, pp. 35-39.

[9] Office of Vocational Education Commission, Moral Ethic Value and Characteristic of Vocational Students, Bangkok: Office of the National Anti-Corruption Commission, 2014, pp. 3-5.
[10] D. Clark. (1995). Why instructional system design? [Online]. Available: http://www.nwlink.com/ donclark/hrd/sat1.html

[11] K. Gustafson and R. M. Branch, Instructional Design Models, Syracuse, NY: ERIC Clearinghouse on Information and Technology, 1997, pp. 45-48.

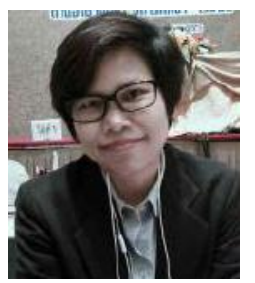

Sorraya Priaoprasit is an instructor in the Department of Business Computer and she is responsible for the following things: teaching many subjects (special project in multimedia technology, multimedia technology in computer-based production, computer for advertising and public relations design, computer graphic design, computer for mass communication technology, and computer multimedia for education). She got the bachelor of education program in computer education, Thonburi Commercial College, Bangkok, Thailand; the master of science, majoring in computer technology, computer information technology, King Mongkut's University of Technology Thonburi (KMUTT), Bangkok, Thailand. She is studying Ph.D. in the Department of Information and Communication Technology for Education, King Mongkut's University of Technology North Bangkok, Thailand.

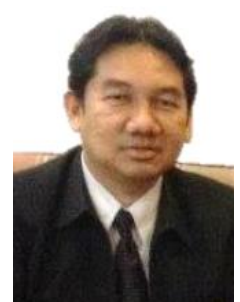

Prachyanun Nilsook is an associate professor at Division of Information and Communication Technology for Education, Faculty of Technical Education, King Mongkut's University of Technology North Bangkok (KMUTNB), Thailand. He received the B.Ed. degree in audio-visual education, from Faculty of Education, Ramkhamhang University, Thailand in 1989. He obtained his M.Ed. degree in educational technology from Faculty of Education, Srinakarinwirot University, Thailand in 1995, and received the Ph.D. degree in educational communications and technology from Faculty of Education, Chulalongkorn University in 2001. From 2001 to present, he works in the field of information and communication technology in education. He has experience in many positions such as the dean, Faculty of Technical Education, Samutsongkhram Technical Collage, and the dean, Faculty of Information and Communication Technology, Samutsongkhram Technical Collage, and the director of Vocational Education Technology Research Center. He received National Teachers Award of the Year in Higher Education 2004 from National Teacher Council, Ministry of Education, and Thailand. He is a membership of professional societies in Association for Educational Technology of Thailand (AETT).

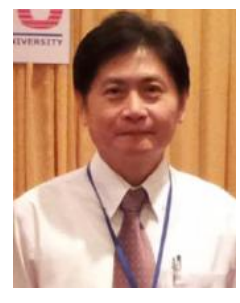

Pallop Piriyasurawong is an assistant professor at Division of Information and Communication Technology for Education, Faculty of Technical Education, King Mongkut's University of Technology North Bangkok (KMUTNB), Thailand. He received the B.Ed. degree in education technology (honor degree). He obtained his M.Ed. degree in educational technology, and received the Ph.D. degree in educational technology in Thailand. 